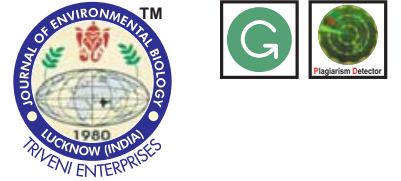

DOI : http://doi.org/10.22438/jeb/38/4/MS-158

\title{
Effect of cassava waste on bioremediation of nitrogenous metabolites and shrimp growth
}

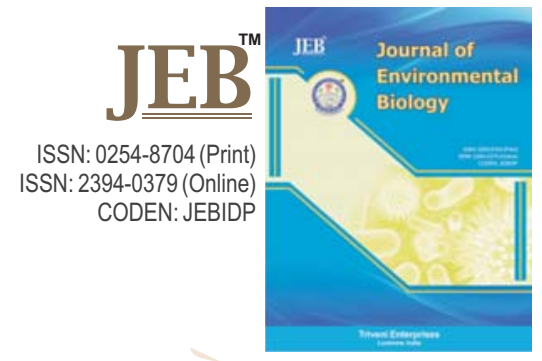

Authors Info

N. Lalitha*, M. Muralidhar, R. Saraswathy, P. Kumararaja and A. Nagavel

Aquatic Animal Health and Environment Division, ICAR Central Institute of Brackishwater Aquaculture, Chennai-600 028, India

${ }^{*}$ Corresponding Author Email : lalitha@ciba.res.in

Key words

Bioremediation,

Cassava waste,

Cassava starch,

Shrimp aquaculture

Publication Info

Paper received : 09.09.2015

Revised received : 29.02 .2016

Re-revised received : 30.07 .2016

Accepted:09.11.2016

\section{Abstract}

Aim: Locally available cheap carbon sources, cassava waste and cassava starch, were tested for their efficiency in decreasing the nitrogenous metabolites, resulting due to accumulation of uneaten feed and excreta at the pond bottom during intensive shrimp aquaculture.

Methodology: Yard experiment was carried out in 500 I Fibre reinforced plastic (FRP) tanks for a period of 105 days with four treatments viz., cassava waste, cassava starch, cassava waste+ cassava starch and control, replicated thrice and statistically randomized with Tiger shrimp, Penaeus monodon (1.71 g). The following water quality parameters - pH, salinity, dissolved oxygen (DO), total ammonia nitrogen (TAN), nitrite nitrogen $\left(\mathrm{NO}_{2}-\mathrm{N}\right)$; microbial parameters in water and sediment - total heterotrophic bacteria count (THBC) and total vibrio count (TVC); proximate composition, fibre fractionation, carbon, hydrogen, nitrogen and sulphur content in cassava waste and cassava starch were analyzed. The growth of shrimp was also studied.

Results: Shrimp growth was significantly high $(p \leq$ 0.05 ) in cassava waste $(11.12 \mathrm{~g})$ treatment followed by cassava starch $(10.4 \mathrm{~g})$, cassava waste + cassava starch $(9.8 \mathrm{~g})$ and control $(8.02 \mathrm{~g})$ at the end of the experiment. Cassava waste, cassava starch and combination of both significantly decreased the concentration of metabolites and had high heterotrophic bacterial population and low total vibrio count compared to control.

Interpretation: It was concluded that addition of cassava waste had positive effect on bioremediation of nitrogenous metabolites, enhancing the growth of shrimp.

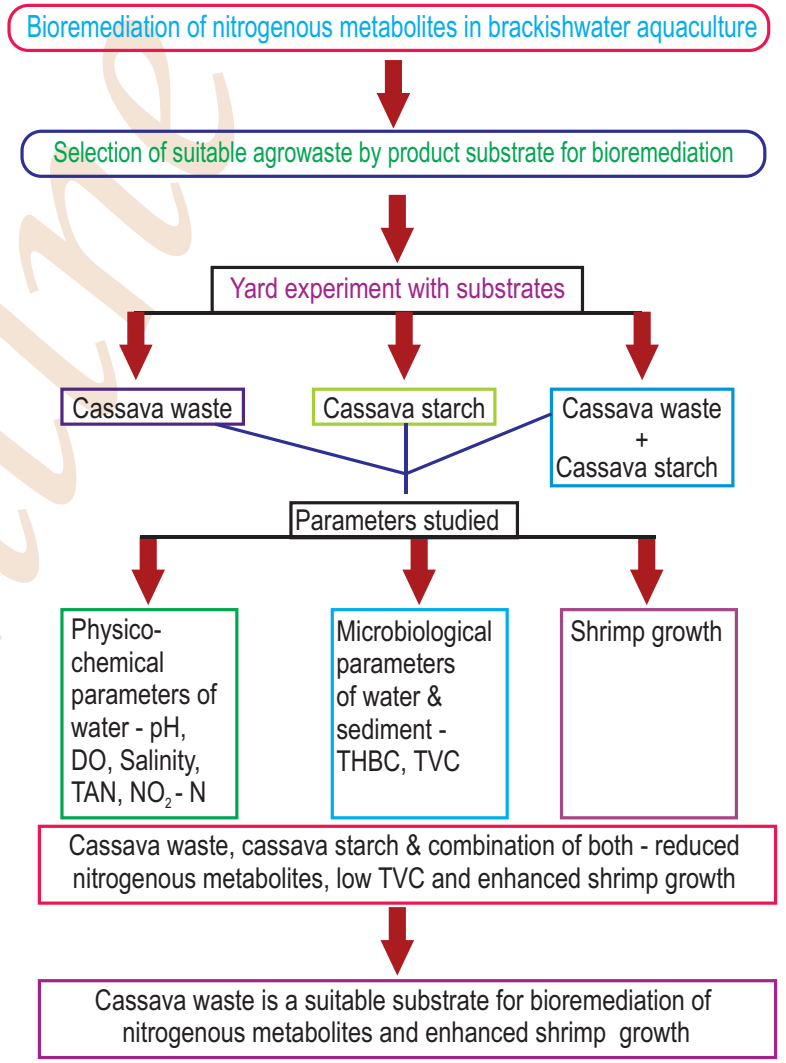




\section{Introduction}

Aquaculture is the fastest booming sector and its output will increase by $35 \%$ in 2022 , whereas the capture fisheries can rise only to $5 \%$. Aquaculture will contribute $53 \%$ of total food consumption sector in 2022 to meet the demand of the growing world population (OECD-FAO, 2013). Intensive aquaculture has resulted in increased concentration of metabolites viz., ammonia, nitrite and sulphide due to accumulation of uneaten feed and excreta at bottom of the pond. The metabolites level must be controlled to maintain good water quality for better survival, growth and production of aquatic animal as well as to reduced the concentration of metabolites in the discharge water. There are various methods to remove or control the metabolites in recirculation aquaculture systems viz., rotating biological contractors, filters (trickling, bead filters and fluidized sand filters). There are technologies like periphyton and biofloc which help to maintain good water quality in grow out ponds, as well as serve as cheap feed source (Crab, 2007).

Cassava waste and sugarcane bagasse are the agroindustrial waste used as raw materials for the production of valueadded products and chemicals (Pandey et al., 2000a and 2000b). Earlier studies indicate that agro-industiral wastes, for example sugarcane bagasse and coconut husk, could efficiently remove ammonia from shrimp farm effluents (Krishnani et al., 2006a and Parimala et al., 2007). These agro waste products are the locally available cheap carbon source that serve as nutrient for growth of heterotrophic bacteria and reduce toxic inorganic nitrogen levels. Cassava waste is a fibrous residue, biodegradable substrate, which provides better surface for attachment of periphyton and probably nutrients through microbial decomposition. Addition of carbonaceous substrates viz.,cassava meal, bagasse and molasses not only helps in controlling toxic inorganic nitrogenous metabolites (Bosma and Vergedem, 2011), but also improves the water quality by reducing the excess of total ammonia nitrogen (Hari et al., 2004). In light of the above, the present study was conducted to evaluate the efficiency of cassava waste with and without carbohydrate addition (cassava starch) for bioremediation of metabolites and shrimp growth performance.

\section{Materials and Methods}

Agro-waste by products and processing of materials : Cassava waste and cassava starch was procured from Sago factory at Kalangani, Nammakkal, Tamilnadu. Cassava waste was soaked in seawater, sundried and kept in oven at $72^{\circ} \mathrm{C}$ for 30 min. Cassava waste and cassava starch were packed in airtight containers until further use.

Experimental setup : Experiment was conducted in the wet lab at Experimental Station of ICAR-Central Institute of Brackishwater Aquaculture (CIBA), Muttukadu. Yard experiment was conducted in 500 I fibre reinforced plastic tanks with juvenile stage of Tiger shrimp, Penaeus monodon $(1.71 \mathrm{~g})$ for a period of
105 days with four treatments viz., cassava waste, cassava starch, cassava waste+cassava starch and control, replicated thrice and statistically randomized. Shrimp for the experiment were procured from shrimp hatchery at Muttukadu, operated by Crustacean Culture Division of CIBA. Brackishwater salinity of 30 ppt used for the experiment was obtained from Bay of Bengal located adjacent to Muttukadu Experimental Station of CIBA. Tanks were filled with brackish water of $30 \mathrm{ppt}$ salinity and with soil base up to the level of $5 \mathrm{~cm}$. The tanks were kept for a period of 11 days for stabilization of the system. Cassava waste was added on $12^{\text {th }}$ day @166 $\mathrm{g}^{-2}$ in a mesh cloth and hung in the tank from top. Tanks were kept at ordinary environment temperature for another 18 days $\left(12^{\text {th }}\right.$ to $30^{\text {th }}$ day) for the growth of periphyton / biofilm on the cassava waste substrate. Juvenile stage shrimp were stocked on 30 day@8nos $\mathrm{m}^{-2}$ in each tank. Cassava starch was added @ $0.62 \mathrm{~kg} \mathrm{~kg}^{-1}$ of feed. Feeding was done @10\% of shrimp body weight. Cassava starch was added by mixing it in a beaker of tank water and distributing over the water surface. Aeration was provided continuously and $30 \%$ water exchange was done once in a week. Cassava waste material replacement was done on the $60^{\text {th }}$ day of the experiment.

Collection of samples and analysis : Water and soil samples were collected on zero (initial), $30^{\text {th }}, 60^{\text {th }}, 90^{\text {th }}$ and $100^{\text {th }}$ day of the experiment for the analysis of physico-chemical properties of water viz., salinity, $\mathrm{pH}$, dissolved oxygen, total ammonia nitrogen and nitrite nitrogen $\left(\mathrm{NO}_{2}-\mathrm{N}\right)$ ) as per standard methods (Strickland and Parsons, 1972; APHA, 2012); total heterotrophic bacterial count (THBC) $\left(0^{\text {th }}, 30^{\text {th }}, 60^{\text {th }}\right.$ and $90^{\text {th }}$ day) and total vibrio count (TVC) $\left(60^{\text {th }}\right.$ and $90^{\text {th }}$ day) in water; THBC $\left(30^{\text {th }}, 60^{\text {th }}\right.$ and $90^{\text {th }}$ day) and TVC $\left(60^{\text {th }}\right.$ and $90^{\text {th }}$ day) in sediment (Gilliland et al., 1976; Austin, 1988) were estimated. The proximate composition and fibre fractionation analysis of cassava waste and cassava starch were done as per the standard procedures (AOAC, 2000).

Ascertaining the toxicity of cassava waste and cassava starch for hydrocyanic acid: There was an apprehension about the use of cassava byproducts, cassava waste and cassava starch due to the presence of hydrocyanic acid $(\mathrm{HCN})$ in it, which may leach in the water when applied. To ascertain this, raw cassava waste and cassava starch were soaked in 100 I fibre reinforced plastic tanks filled with 34 ppt water and analyzed the experimental water and substrate samples from the experimental tanks for toxicity of $\mathrm{HCN}$ at different time intervals $(24,48,72$ and $96 \mathrm{hrs}$ ) as per standard procedure (AOAC,2000)

Statistical analysis: ANOVA was used and the difference between treatments means was compared by Duncan's multiple range test using SPSS 16.0 software package (SPSS Inc., Chicago, IL, USA).

\section{Results and Discussion}

Proximate composition, fiber fractionation and carbon, hydrogen, nitrogen, sulphur of cassava waste and cassava starch 
were done. Nitrogen free extract (soluble carbohydrate starch and sugar) was higher in cassava waste $(75.5 \%)$ than sugarcane bagasse (42. $4 \%$, Salman et al., 2011). Lignin, a less degradable constituent by microorganisms was less in cassava waste $(1.4 \%)$ as compared to sugarcane bagasse $(12.63 \%$, Sukumaran and Seshadri, 2009) which makes its application easier without any pretreatment. Fibre content in the cassava starch was not detectable.

Hydrocyanic acid was not detected (detection limit of 0.02 $\left.\mathrm{mg}^{-1}\right)$ in water and substrate samples of experimental tanks at different time intervals $(24,48,72$ and $96 \mathrm{hrs})$. The raw materials were prepared by soaking, sun drying, oven drying and the unprocessed samples did not contain HCN level higher than 0.02 $\mathrm{mg} \mathrm{I}^{-1}$. Further, it was safe to conclude that toxicity due to hydrocyanic acid might not be a serious problem as safe level of $\mathrm{HCN}$ recommended in cassava food by Codex Alimentarius Commission of FAO/WHO, (1988) was as high as $10 \mathrm{mg} \mathrm{l}^{-1}$. In the present study, sample preparation by soaking, sun drying and oven drying might have removed maximum $\mathrm{HCN}$. These results are in confirmation with the reports of Lukuyu et al., 2014.

Water quality parameters like $\mathrm{pH}$, dissolved oxygen and salinity, reported in the present study did not show significant difference among treatments during the study period and were within in the normal range for shrimp growth (Ferreira et al., 2011).

Total ammonia nitrogen reduced significantly on $30^{\text {th }}$ day in experimental tanks provided with cassava waste alone $\left(0.19 \mathrm{mg} \mathrm{l}^{-1}\right)$ followed by cassava waste + cassava starch $\left(0.21 \mathrm{mgl}^{-1}\right)(p \leq 0.05)$ when compared control $\left(0.42 \mathrm{mg} \mathrm{l}^{-1}\right)$. Similar trend was observed on $60^{\text {th }}$ and $90^{\text {th }}$ days of the experiment (cassava waste -0.28 and $0.30 \mathrm{mg} \mathrm{l}^{-1}$ followed by cassava starch -0.37 and $0.36 \mathrm{mg} \mathrm{l}^{-1}$ and cassava waste + cassava starch -0.45 and $0.44 \mathrm{mgl}^{-1}$, compared to control 0.57 and $0.90 \mathrm{mgl}^{-1}$, respectively). On $100^{\text {th }}$ day of the experiment cassava waste registered low total ammonia nitrogen level $\left(0.24 \mathrm{mg} \mathrm{l}^{-1}\right)$ compared to control $\left(0.93 \mathrm{mg} \mathrm{l}^{-1}\right)$. Hence, among the treatments cassava waste followed by cassava starch and cassava waste+cassava starch showed comparatively lower total ammonia nitrogen (Fig. 1a).

Nitrite nitrogen on $30^{\text {th }}$ day of the experiment recorded significantly $(p \leq 0.05)$ low values in treatments with cassava waste $\left(0.028 \mathrm{mg} \mathrm{l}^{-1}\right)$ followed by cassava waste + cassava starch $\left(0.031 \mathrm{mg} \mathrm{l}^{-1}\right)$, compared to control $\left(0.045 \mathrm{mg} \mathrm{l}^{-1}\right)$. Similarly low levels of nitrite nitrogen levels were noted on $60^{\text {th }}$ day and $90^{\text {th }}$ day of the experiment in cassava waste $\left(0.17\right.$ and $\left.0.18 \mathrm{mgl}^{-1}\right)$ followed by cassava starch $\left(0.19\right.$ and $\left.0.35 \mathrm{mg} \mathrm{l}^{-1}\right)$, cassava waste+cassava starch $\left(0.26\right.$ and $\left.0.58 \mathrm{mg} \mathrm{l}^{-1}\right)$, respectively compared to control $\left(0.46\right.$ and $\left.0.69 \mathrm{mg} \mathrm{l}^{-1}\right)$. Further, similar trend was seen on $100^{\text {th }}$ day of the experiment with lowest nitrite nitrogen levels in cassava waste $\left(0.34 \mathrm{mg} \mathrm{l}^{-1}\right)$ and other treatments, compared to control $\left(0.87 \mathrm{mg} \mathrm{l}^{-1}\right)$. Hence, the treatments cassava waste, cassava starch and cassava waste + cassava starch showed comparatively low nitrite nitrogen (Fig. 1b).
The trend of decreasing metabolites in the present study agrees with the findings that addition of carbohydrate and periphyton substrates lowers the nitrogenous metabolites (Asaduzzaman et al., 2008; 2009; Arnold et al., 2009). Further, addition of glucose, cassava meal cellulose powder, tapioca starch, molasses and tapioca flour in the fish, shrimp and prawn ponds were reported to enhance the water quality (Avnimelech, 1999; Hari et al., 2004; Buford 2004; Asaduuzzaman et al., 2008). Addition of these sources increases the microbes assembly and at the same time the nitrogenous metabolites (Total ammonia nitrogen and nitrite-N) were controlled (Bosma and Vergedem, 2011). Taken together, the present study indicates that the addition of cassava waste can significantly lower the nitrogenous metabolites levels in a similar way.

Treatments cassava waste+cassava starch, cassava waste and cassava starch showed comparatively high total heterotrophic bacteria count (THBC) in water (Fig. 2a). THBC among the treatments ranged from 2.25 to $2.4 \times 10^{4} \mathrm{CFU} \mathrm{ml}{ }^{-1}$ on zero (initial) day of the experiment, whereas on $30^{\text {th }}$ day of the experiment significantly $(p \leq 0.05)$ high THBC $\left(x 10^{4} \mathrm{CFU} \mathrm{ml}{ }^{-1}\right)$ in water were observed in treatments with cassava waste (15.7) followed by cassava waste + cassava starch (12.55) and cassava starch (6.9) compared to control (6.61). However, cassava waste + cassava starch showed higher THBC (in $\times 10^{4} \mathrm{CFU} \mathrm{ml}{ }^{-1}$ ) values on $60^{\text {th }}$ day of the experiment (26.75) followed by cassava waste (25.3) and cassava starch (22.05) compared to control (9.75). Similar trend of higher THBC in $\times 10^{4} \mathrm{CFU} \mathrm{ml}^{-1}$ was observed on $90^{\text {th }}$ day of the experiment in cassava waste+cassava starch (42.7) treatment followed by cassava waste (34.6) and cassava starch (33.5) compared to control (14.1).

The sediment values of THBC values on $30^{\text {th }}$ day of the experiment (in $\times 10^{5} \mathrm{CFU} \mathrm{ml}{ }^{-1}$ ) was significantly $(p \leq 0.05)$ high in treatment with cassava waste (24.1) followed by cassava waste + cassava starch (23.5) and cassava starch (9.8) compared to control (9.2). Similar trend was recorded THBC (in $\times 10^{5} \mathrm{CFU} \mathrm{ml}{ }^{-1}$ ) on $60^{\text {th }}$ day and $90^{\text {th }}$ day; cassava waste + cassava starch (40.7 and 53.4 respectively); cassava waste (35.4 and 48.5 respectively); cassava starch (25.5 and 41.5 respectively followed by control (20.1 and 29.3 respectively). Taken together, treatment with cassava waste + cassava starch, cassava waste and cassava starch showed comparatively high THBC (Fig. 2b).

Addition of carbonaceous materials with higher nitrogen free extract helps to increase heterotrophic bacterial count and hence control of metabolites (Avnimelech, 1999; Hari et al., 2004). In the present study, an increase of THBC in water and sediment in the treatment groups at 60 and 90 days was observed in cassava waste + cassava starch followed by cassava waste and cassava starch and they utilized the nitrogen, reduced the metabolites concentration and maintained the water quality compared to control. Addition of carbonaceous substrate were found to stimulate the bacterial growth (Avnimelech, 1999) and 

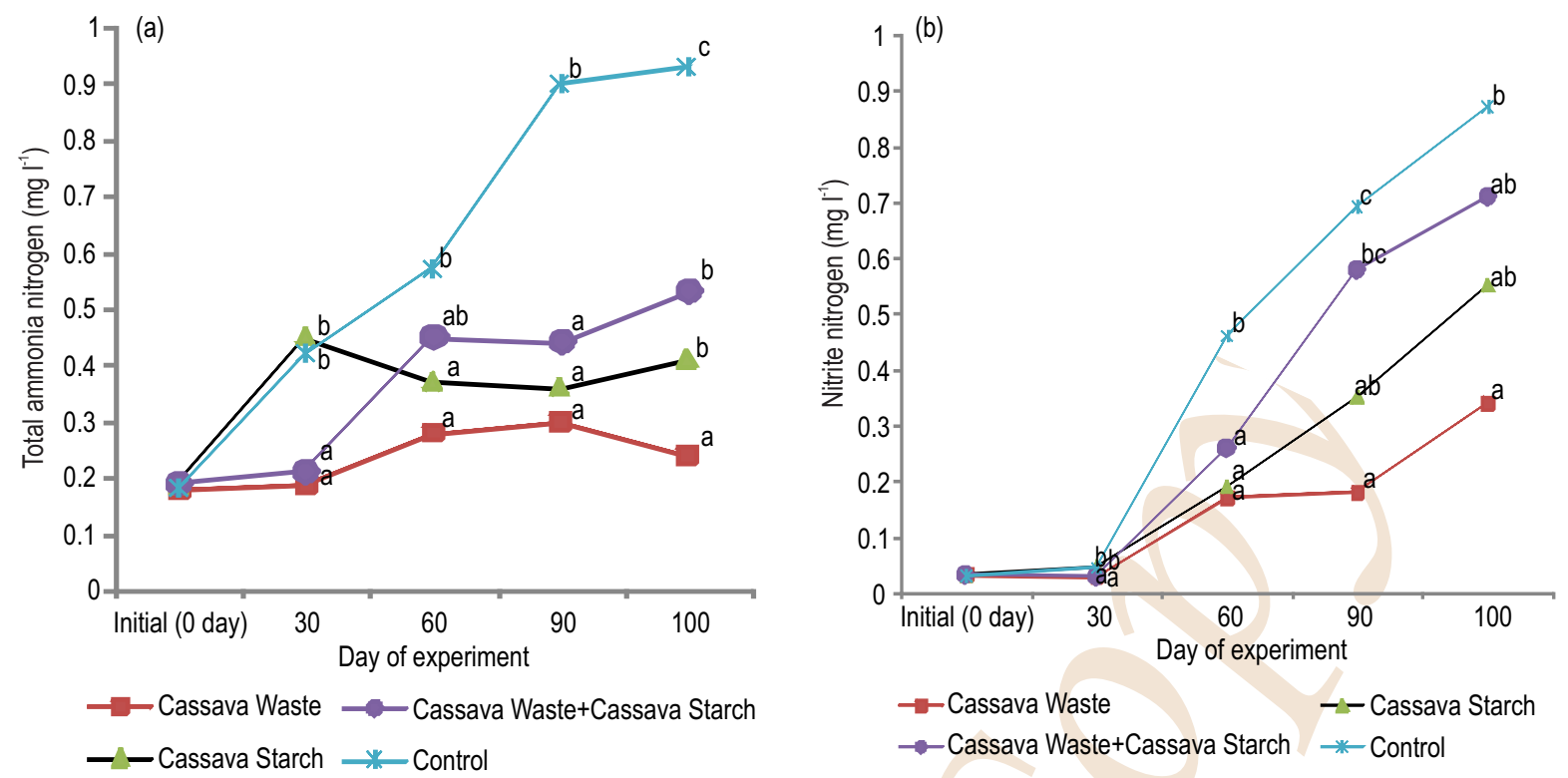

Fig. 1: Effect of treatments on (a) total ammonia nitrogen and (b) nitrite nitrogen in water
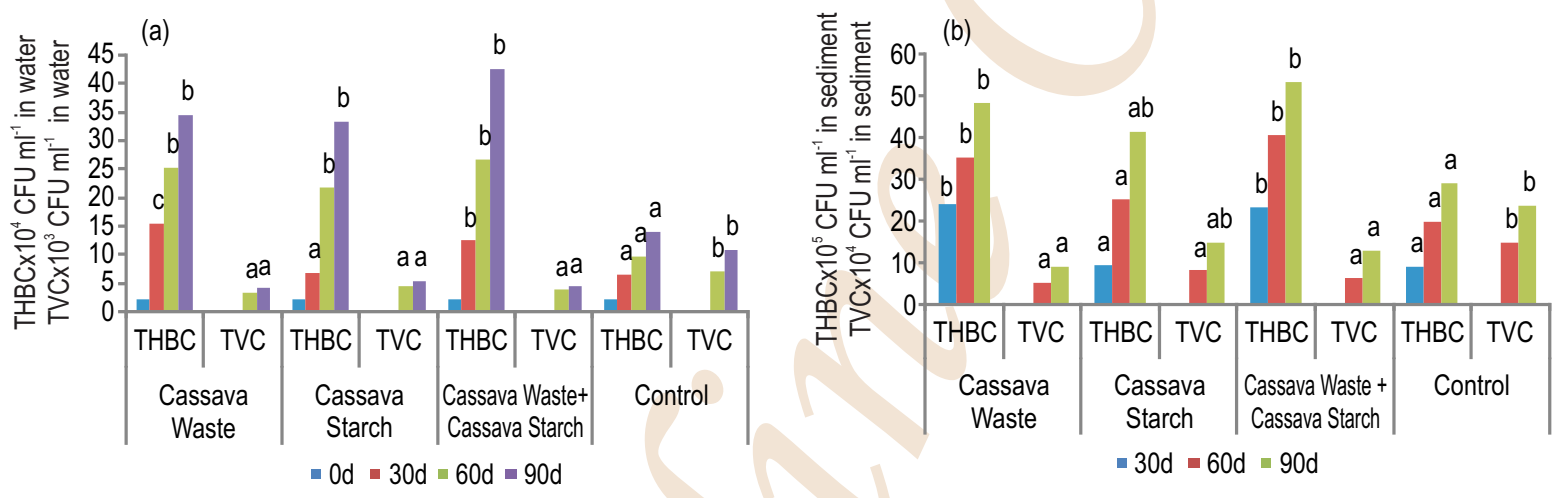

Fig. 2 : Effect of treatments on total heterotrophic bacteria and total vibrio count in (a) water and (b) sediment

Azaduzzaman et al. (2010) reported increased THBC in water, sediment and substrate due to addition of tapioca starch. Further, an increased microbial assembly was reported by the addition of molasses and cassava meal (Bosma and Vergedem, 2011); tapioca flour (Hari et al., 2004); raw fiber and dried bagasse fibers (Krishnani et al., 2006b). In addition, bagasse efficiently removed the total ammonia nitrogen (Krishnani et al., 2006a) and nitrite nitrogen from shrimp farm waste water (Krishnani et al., 2006b) may be due to the periphytic bacterial growth. Taken together, the increase in bacterial growth may reduce the ammonium concentration by nitrogen uptake for its growth and it reduces the metabolite concentration in the water (Crab et al., 2007). However, Patil et al. (2016) reported low THBC in water than sediment.
The treatments with cassava waste, cassava waste + cassava starch, cassava starch showed comparatively low total vibrio count in water (Fig. 2a). The TVC of water (in $\times 10^{3} \mathrm{CFU} \mathrm{ml}^{-1}$ ) on $60^{\text {th }}$ day of the experiment registered significantly $(p \leq 0.05)$ low in treatment with cassava waste (3.5) followed by cassava waste +cassava starch (3.9), cassava starch (4.7) compared to control (7.3). Similar trend was observed for TVC of water in $\times 10^{3} \mathrm{CFU} \mathrm{ml}{ }^{-1}$ on $90^{\text {th }}$ day of the experiment in different treatments (cassava waste -4.2 ; cassava waste + cassava starch -4.5 ; cassava starch -5.4 compared to control-11.1).

A low vibrio count in sediment (in $\times 10^{4} \mathrm{CFU} \mathrm{m}^{-1}$ ) on $60^{\text {th }}$ day of the experiment was registered with cassava waste + cassava starch (6.5) compared to control (15.1). Similar trend 
was observed for TVC of sediment $\left(\times 10^{4} \mathrm{CFU} \mathrm{ml^{-1 }}\right)$ on $90^{\text {th }}$ day of the experiment (cassava waste -9.3 followed by cassava waste + cassava starch - 13.2, cassava starch - 15.1 compared to control 23.7). Taken together, the treatments cassava waste, cassava waste+cassava starch and cassava starch showed comparatively low TVC in sediment (Fig. 2b).

A low vibrio count in the treatments may be due to the establishment of beneficial microorganisms replacing the disintegrating or undesirable microorganisms (Boyd and Gross, 1998). The pathogenic organisms growth was slowed down in response to the increase and competition of the beneficial microorganism thereby stable and healthy environment was provided to the growth of animals (Zhou et al., 2009). Crab et al., (2007) reported heterotrophic microbial biomass impact on controlling the pathogenic bacteria. Hence, a low vibrio load reported in the present study with cassava waste treatment might be due to the establishment of beneficial microorganisms compared to control.

The mean average weight of shrimp reported at the end of experiment was significantly $(p \leq 0.05)$ high in the treatment groups with cassava waste $11.12^{\mathrm{a}} \mathrm{g}$ followed by cassava starch $10.4^{\mathrm{b}} \mathrm{g}$, cassava waste + cassava starch $9.8^{\mathrm{c}} \mathrm{g}$ compared to control $8.02^{\mathrm{d}} \mathrm{g}$. The enhanced growth in the cassava waste, cassava starch and cassava waste + cassava starch treatment group might be due to the maintenance of good water quality and healthy environment by the reduction of metabolites (total ammonia nitrogen, nitrite-N), high THBC and low TVC in water and sediment.

Cassava waste inclusion might have stimulated formation of biofilm with beneficial microorganisms formation on its submerged surface and contributed for increased shrimp growth. These findings are in agreement with the report of Bosma and Vergedem (2011) and Arnold et al. (2006) using artificial substrate in a study with Penaeus monodon. Further, similar findings were observed in the intensive culture of Litopenaeus vannamei with substrate addition (Bratvold and Browdy, 2001; Moss and Moss, 2004). In conclusion, cassava waste as a substrate has the potential for bioremediation of metabolites and enhanced growth of Tiger shrimp, Penaeus monodon.

\section{Acknowledgment}

We thank the Director, ICAR - Central Institute of Brackishwater Aquaculture for the facilities provided during the research work.

\section{References}

Agricultural Outlook 2013-2022: Organization for Economic Cooperation and Development(OECD) - Food and Agriculture Organization (FAO) of the United Nations (2013).

American Public Health Association: American Water Works Association
(AWWA), Water Environment Federation (WEF). $22^{\text {nd }}$ Edn., Standard Methods for the Examination of Water and Waste Water. American Public Health Association, Washington, DC (2012)

Association of Official Analytical Chemists (AOAC): Official Methods of Analysis $17^{\text {th }} \mathrm{Edn}$., Association of Official Analytical Chemists, Gaithersburg, M.D.(2000).

Arnold, S.J, M.J. Sellars, P.J. Crocos and G.J. Coman: Intensive production of juvenile tiger shrimp Penaeus monodon: An evaluation of stocking density and artificial substrates. Aquaculture, 261, 890-896 (2006).

Arnold, S.J, F.E. Coman, C.J. Jackson and S.A. Groves: High-intensity, zero water-exchange production of juvenile tiger shrimp, Penaeus monodon: An evaluation of artificial substrates and stocking density. Aquaculture, 293, 42-48(2009).

Asaduzzaman, M., M.A. Wahab, M.C.J. Verdegem, S. Huque, M.A. Salam and M.E. Azim: $\mathrm{C} / \mathrm{N}$ ratio control and substrate addition for periphyton development jointly enhance freshwater prawn Macrobrachium rosenbergii production in ponds. Aquaculture, 280, 117-123 (2008).

Asaduzzaman, M., M.A. Wahab, M.C.J. Verdegem, M.N. Mondal and M.E. Azim: Effects of stocking density of freshwater prawn Macrobrachium rosenbergii and addition of different levels of tilapia Oreochromis niloticus on production in $\mathrm{C} / \mathrm{N}$ controlled periphyton based system. Aquaculture, 286, 72-79 (2009).

Asaduzzaman, M., M.M. Rahman, M.E. Azim, M.A., Islam, M.A. Wahab, M.C.J. Verdegem and J.A.J. Verreth: Effects of $\mathrm{C} / \mathrm{N}$ ratio and substrate addition on natural food communities in fresh water prawn monoculture ponds. Aquaculture, 306, 127-136 (2010).

Austin, B.: Methods in Aquatic Bacteriology. Wiley, New York, p. 425 (1988).

Avnimelech, Y.: Carbon/Nitrogen ratio as a control element in aquaculture systems. Aquaculture, 176, 227-235(1999).

Bosma, R.H. and M.C.J. Verdegem: Sustainable aquaculture in ponds: Principles, practices and limits. Livest. Sci.,139, 58-68 (2011).

Boyd, C.E. and A. Gross: Use of probiotics for improving soil and water quality in aquaculture ponds (Eds.: T.W. Flegel). BIOTEC The National Center for Genetic Engineering and Biotechnology, Thailand, p.101 (1998).

Bratvold, D. and C.L. Browdy: Effects of sand sediment and vertical surfaces (AquaMats ${ }^{\mathrm{TM}}$ ) on production, water quality and microbial ecology in an intensive Litopenaeus vannamei culture system. Aquaculture, 195, 81-94 (2001).

Burford, M.A., P.J. Thompson, McIntosh, R.H. Bauman and D.C. Pearson: The contribution of flocculated material to shrimp (Litopenaeus vannamei) nutrition in a high-intensity, zeroexchange system. Aquaculture, 232, 525-537 (2004).

Codex Alimentarius Commission: Report of the Eighth Session of the Codex Coordinating Committee for Africa. Cairo, FAO/WHO (1988).

Crab, R., Y. Avinimelech, T. Defoirdt, P. Bossier and W. Verstraete: Nitrogen removal techniques in aquaculture for a sustainable production. Aquaculture, 270, 1-14 (2007).

Ferreira, N.C, C. Bonetti and W.Q. Seiffert: Hydrological and water quality indices as management tools in marine shrimp culture. Aquaculture, 318, 425-433 (2011).

Gilliland, S.E., F.F. Busta, J.J. Brinda and J.E. Campbell: Aerobic plate count. In: Compendium of Methods for the Microbiological Examination of Foods (Ed.: M.L. Speck). American Public Health Association, Washington, pp. 107-130(1976). 
Hari, B., B.M. Kurup, J.T. Varghese, J.W. Schrama and M.C.J. Verdegem: Effects of carbohydrate addition on production in extensive shrimp culture systems. Aquaculture, 241, 179-194 (2004).

Krishnani K.K., V.B.P. Parimala, B.P. Gupta, I.S. Azad, X. Meng and M. Abraham: Bagasse-assisted bioremediation of ammonia from shrimp farm wastewater. Wat. Environ. Res., 78, 938-950 (2006a).

Krishnani K.K., V.Parimala, B.P. Gupta, I.S. Azad and M.S. Shekhar: Bioremediation of nitrite from brackishwater using lignocellulosic agricultural waste-bagasse. Asi. Fish. Sci.,19, 429-444 (2006b).

Lukuyu, B., I. Okike, A. Duncan, M. Beveridge and M. Blummel: Use of cassava in livestock and aquaculture feeding programs. International Livestock Research Institute, Ethiopia (2014).

Moss, K.R.K. and S.M. Moss: Effects of artificial substrate and stocking density on the nursery production of Pacific white shrimp Litopenaeus vannamei. J. World Aquac. Soc., 35, 536-542 (2004).

Pandey, A., C.R. Soccol, P. Nigam and V.T. Soccol: Biotechnological potential of agro-industrial residues. I: Sugarcane bagasse. Biores. Technol., 74,69-80(2000a).

Pandey, A., C.R. Soccol, P. Nigam, V.T. Soccol, L.P.S. Vandenberghe and R. Mohan: Biotechnological potential of agro-industrial residues. Il: cassava bagasse. Biores. Technol., 74, 81-87 (2000b).
Parimala, V., K.K. Krishnani, B.P. Gupta, R. Ragunathan, S.M. Pillai and P. Ravichandran: Removal of ammonia and nitrite from coastal water using low-cost agricultural waste. Bull. Environ. Contam. Toxicol., 78, 288-293 (2007).

Patil, P.K., M. Muralidhar, H.G. Solanki, P.P. Patel, K. Patel and C. Gopal: Effect of culture intensity and probiotics application on microbiological and environmental parameters in Litopenaeus vannamei culture ponds. J. Environ. Biol., 37, 21-29 (2016).

Salman, F.M., R. Salama, A.E. Khattab, S.M. Soliman and Y.A. El. Nomeary: Chemical, biological and biochemical treatments to improve the nutritive values of sugarcane Bagasse (SCB): Chemical composition, scanning electron microscopy, in vitro evaluation, nutrients digestibility and nitrogen utilization of untreated or treated SCB. Life Sci. J., 8, 351 -363 (2011).

Sugumaran, P. and S. Seshadri: Evaluation of selected biomass for charcoal production. J. Scient. Indus. Res., 68, 719-723 (2009).

Strickland, J.D.H. and T.R.A. Parsons: A Practical Hand Book of Seawater Analysis. Bulletin, 167. Fisheries Research Board of Canada, Ottawa, p. 310 (1972).

Zhou, Q., K. Li, X. Jun and L. Bo: Role and functions of beneficial microorganisms in sustainable aquaculture. Biores. Technol.,100, 3780-3786 (2009) 